LOCAL WISDOM, 12 (1): 46 - 60, 2020
Local Wisdom Scientific Online Journal
ISSN: 2086-3764

\title{
Community Assistance for Forest and Land Fire Prevention (Karhutla) in Gelebak Dalam Village, Banyuasin District, South Sumatra
}

\author{
Yenrizal Tarmizi ${ }^{1^{*}}$, Muhammad Sirozi ${ }^{2}$ \\ ${ }^{1}$ Department of Communication, Faculty of Social and Politics Science, UIN Raden Fatah, Indonesia \\ 2Department of Islamic Management Education, Faculty of Tarbiyah and Teacher Training UIN \\ Raden Fatah, Indonesia \\ Corresponding Author: : yenrizal_uin@radenfatah.ac.id
}

\section{Abstract}

Keywords: $\quad$ Forest and land fires (karhutla) are events that always occur every year in Indonesia. South Sumatra is one of the regions contributing to

forestand land the forest and land fires. Various attempts have been made but it still

fires, assistance, does not work. This paper aims to describe other methods of dealing environment with forest and land fires, namely the assistance method. Its location is in Gelebak Dalam Village, South Sumatra. The method used is participatory action research. The results show that community participation is able to prevent forest and land fires and create new methods in assistance.

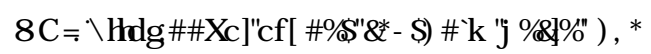

$\square$

2017 The Authors. Published by GKAK UNMER Malang $\square$

*Corresponding Author: yenrizal_uin@radenfatah.ac.id
}

\section{Introduction}

The occurrence of forest and land fires (karhutla) in South Sumatra is a phenomenon that continues to recur. Since the 2014 forest and land fires, continued into 2015, and continues to occur in 2016, 2017, 2018 and 2019. Every time the dry season comes, we can be sure that some areas in this area have been burned. Data from BNPB states that the area of burned area reached 1.2 million hectares in 2015 and by 2019 it had reached almost 1 million hectares. The dominant area of this burning area turned out to be a peat swamp area.

The effect of the forest and land fires was the thickening of the haze which struck various regions, including Palembang and several nearby areas. Even in 2015, Singapore and Malaysia were also affected. South Sumatra is also known as the smoke exporting province. Therefore, it is not surprising that in 2015, President Jokowi even took the time to work in the OKI Regency for several days, specifically monitoring fire suppression efforts as well as seeing the causes of fires. 


\section{Community Assistance for Forest and Land Fire Prevention (Karhutla) in Gelebak Dalam Village, Banyuasin District, South Sumatra \\ Yenrizal Tarmizi, Muhammad Sirozi}

On a broad scale, the occurrence of forest and land fires is not only experienced by South Sumatra. Noted there are at least 4 top priority provinces namely South Sumatra, Riau, West Kalimantan, and Central Kalimantan. This priority is based on the extent of the burned peat area. But in fact, the forest and land fires that occurred not only in the area, many other areas also burned, such as Jambi, parts of Lampung, South Kalimantan, and Papua. All areas that have peat areas are almost burned.

South Sumatra itself is one of the areas most affected by forest and land fires. Based on Perpres No. 1 of 2016, two regencies in South Sumatra, namely Ogan Komering Ilir (OKI) and Banyuasin Regencies were designated as priority areas for peat restoration. This is not without reason because the 2015 forest and land fires phenomenon has an extraordinary effect on all components of society.

The causes of forest and land fires can be identified as follows, first, the method of opening agricultural land which still relies on the method of burning. Generally this is done by community groups who want to open agricultural land. Second, neglect of land, especially peat areas, land is not cultivated and not maintained. These lands are generally swamps (partly peat swamps), which in the dry season are very vulnerable to burning. Third, high temperatures due to long drought. This dry season is commonly referred to as the el nino phenomenon, which causes drought for up to 4-6 consecutive months. Fourth, the dryness of the swamps, especially the peat swamps, either as a result of deliberate actions or not. Peat swamps actually become water reserves, and in the dry season when the swamp is dry it will potentially burn. Fifth, illegal logging practices are still commonly found. Illegal logging, reducing forest cover, then firewood during the dry season. In addition, non-technical issues also influence such as the matter of coordination between agencies that is not optimal and the mental attitude of some parties who are not committed to environmental sustainability. Likewise the matter of policies that are not firm and clear in the protection of water catchment areas, including law enforcement efforts that are often less balanced and less consistent.

One area in South Sumatra that is prone to burning is Gelebak Dalam Village in Banyuasin District. This area is indeed dominated by swamps, both peat swamps and mineral soil swamps. This area covers around 3000 ha. Every year this village is always a subscriber to the forest and land fires. In 2014 and 2015, forest and land fires always plagued the region. The reason is that the land is too dry and the water flow is difficult. Gelebak Dalam Village is a village that is the main source of livelihood from paddy farming, therefore the existence of land is very much needed. However, in the dry season, paddy fields are dry and very potential for forest and land fires. This is a serious problem for local residents, on one hand they have dependence on land, but on the other hand have limitations to distribute water to existing land.

Various efforts have been made by residents such as and the local village government to prevent forest and land fires. In 2016, the local village government collaborated with Korem 044 Garuda Dempo to make various efforts to empower the community to be able to actively protect their land. But the fact of forest and land fire still has the potential to occur. The irrigation development program was also carried out to help irrigate the residents' rice fields, but still forest and land fire arose. The pattern of law enforcement by patrolling and prosecuting was also carried out, but to no avail.

Other efforts are then needed that lead to the position and condition of citizens in an area, which places them able to carry out routine activities but remain in the context of 
protecting the environment from forest and land fires. Community facilitation is one thing that can be done, with the pressure that together with residents create a new formula so that existing activities do not disturb the environmental balance.

Research from Priyo Subekti, Yanti Setianti, and Hanny Hafiar shows that community facilitation is something that is needed whose emphasis is on empowerment based on the potential of the community. The research carried out shows that many things can be developed to prevent the community from damaging behavior in natural conditions, including the empowerment of alternative livelihoods that can be done.

A study from the IRE Institute also shows that community assistance or often referred to as community empowerment, is indeed needed, although on some sides it still finds many challenges and obstacles, including the role of actors that are not synergistic, the availability of infrastructure, to the content of policies that do not support . Therefore, an asymmetrical approach is needed, that is, an approach that is in favor of the real conditions of a community.

While Irkham Widiono and Sarmin said that community service activities aim to develop community insights and abilities (in this case farmers) in implementing integrated farming systems. Efforts are being made to increase the knowledge and skills of citizens in animal husbandry, plant cultivation, and waste management. Community development is carried out with an active community participation approach (learning centered on farmer farmers) and mentoring by experts and practitioners of integrated livestock farming. In addition, institutional development and cooperation networks are also carried out with various related parties. Everything is done based on local potential and ability to do so.

The study of assistance activities in the context of forest and land fire vulnerable people is still very minimal. But the process and mechanism of assistance is not much different, the difference is only in the locus of study and the characteristics of the problem.

Therefore, based on the initial understanding that the community has a relationship with the natural environment, also has relevance to the occurrence of forest and land fires, then strategic efforts are needed to prevent forest and land fires. The focus that must be done is how to empower the Gelebak Dalam village community to be more concerned and more alert to the occurrence of forest and land fires. The most important thing is how to create a community that is aware of forest and land fire and is aware of the power of its environment.

Gelebek Dalam Village which is the focus of the assisted area is in Sungai Pinang District, Banyuasin Regency, South Sumatra. The population reaches 2,100 people, 542 households, a total land area of around 800 ha for settlements and rice fields, the rest is not yet processed or has been turned into a rubber plantation. The economic condition of residents is at the middle level with income from around 6,700 tons of paddy per year or Rp. 55 billion / year. This area is known as the center of rice in South Sumatra. Therefore, the livelihoods of villagers are generally rice farming.

Rice fields do look very wide and are already largely used. It's just that, although this area is a paddy field, but in the dry season, Gelebek Dalam is often the location of forest and land fires (forest and land fires. In 2014, 2015 and a small portion also occurred in 2016, 2017 and 2018, fires struck this village. Hal this is very possible because some of the land is still not yet being cultivated, some is also in the form of shallow peat swamps. The hotspots are very potential to occur at this location. 


\section{Community Assistance for Forest and Land Fire Prevention (Karhutla) in Gelebak Dalam Village, Banyuasin District, South Sumatra \\ Yenrizal Tarmizi, Muhammad Sirozi}

Until now, efforts that have been made by residents to face the dry season and prevent fires have not yet appeared to be optimal. Some residents still use the slash and burn method (sonor) because this method is very effective in clearing land. Effective in the sense of easy and low-cost.

Therefore, the issue of forest and land fire is a serious concern that must be done because it will be related to various inherited problems. The large size of the forest and land fires will cause haze problems to the city of Palembang and other regions, even to neighboring countries.

The main obstacle faced by citizens of forest and land fires is the problem between clearing land with a ban on burning land. Until now residents have not found an effective method, although various innovations have been applied, such as collaborating with the TNI, BNPB, the Police and also with related SKPD. Until now this business has not produced maximum results. Whenever dry season comes, that worry always arises.

Meanwhile, if viewed from the village position, this location is close to Palembang and can even be said to be a buffer zone. The distance from the city center is only about 15 $\mathrm{km}$ with a distance of about 30 minutes. Therefore access to this village can be said to be very easy.

\section{Research Methode}

The Gelebek Dalam village area is not an area for researchers. Researcher's knowledge about this location is good enough, in the sense that the method of gaining access is no longer needed because there has been initial research done before. Researchers already have a good relationship with the local community, therefore the initial relationship or the introduction of researchers is not needed anymore. The researcher only needs to continue to focus the problem and then implement the assisted methods that can be done.

Sequential assistance is carried out by referring to the idea of participatory research, the aim of which is to make changes in the area. The stages of activities as well as the mentoring methods that will be carried out are as follows:

1. Recognition of problems and problem deepening

This was done after the initial survey was conducted to find out and show problems. Researchers will explore the problem and identify more specifically the profile of the problem.

2. Fusion with the community

This stage is to build togetherness and participation with the community so that patterns of relationships are more intimate and integrated.

3. Describe the identification of problems with the community

This stage is carried out together with the community to describe and identify the problem in detail and detail

4. Determine alternative solutions to the problem

This stage is to choose from the many solutions, what alternatives are applied.

5. Implement alternative solutions to problems

This section is the practice of solutions that have been chosen, implemented with the community 
6. Evaluation and reflection

The final stage is to see and review all the things that have been done and what weaknesses have been experienced so far, so that solutions can be obtained in the future.

In the assistance process, the time period needed is around 8 months with the effective time in the assistance process is 4 months. This is with the assumption that researchers already know the location of Gelebak Dalam Village and have conducted preliminary research on various problems found.

For the effectiveness of assistance, researchers collaborate with other elements as needed. The parties involved are from agriculture, fisheries scientists and also from disaster management agencies. Researchers continue to be the coordinator and other units to support implementation. This research road map can be seen from the following chart.
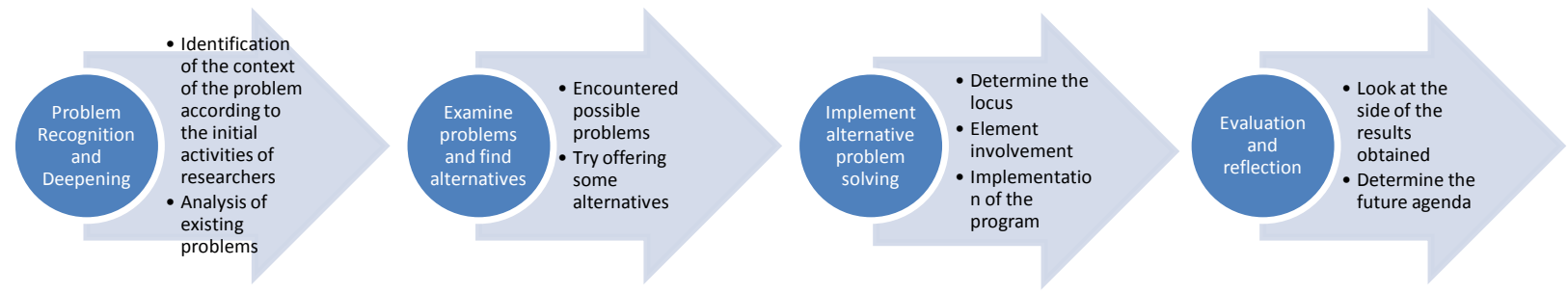

\section{Chart 1. Research Road Map}

It appears in the chart above that the road map for this research was carried out in stages. In accordance with the context of this research, the road map will be carried out in accordance with the available resources. It could be that these stages only reach the determination of alternative solutions. In time it will be continued by trying to find other solutions or continue at the implementation stage. It's just that the stages will be carried out consistently. Therefore, the assistance and involvement of researchers will continue to be done routinely. In this case, the involvement of researchers so far, is very beneficial because researchers already know this location.

\section{Assistance Results}

The results of this assistance are described in the form of a road map of assistance that starts from the stage of problem recognition to the application of problem solutions. Each is outlined to indicate that the assistance process is carried out in stages.

\section{Problem Recognition}

In the context of this research area, namely in Gelebak Dalam Village with a focus on preventing forest and land fires, several methods used in the introduction of the problem include collecting documents related to forest and land fires in South Sumatra, documents and literature on community empowerment, and documents on Desa Gelebak Dalam alone.

The collection of this document was carried out by the method of literature, searching on the internet, and collecting documents directly in the Gelebek Dalam Village 


\section{Community Assistance for Forest and Land Fire Prevention (Karhutla) in Gelebak Dalam Village, Banyuasin District, South Sumatra \\ Yenrizal Tarmizi, Muhammad Sirozi}

itself. This process was carried out throughout the study, from the beginning to the process of writing the report. Through this documentation process, obtained various important information related to the object under study. Documents that have been collected and then become important information in problem analysis are: (1) UU No. 32 tahun 2007 on the Environment, (2) PP No. 71 of 2014 concerning the management and protection of peatland ecosystems, (3) PP No. 27 of 2012 concerning Environmental Permits, (4) PP No. 24 of 2001 concerning Environmental Damage and / or Pollution Control Related to Forest and Land Fires, (5) PP Number 57 of 2016 concerning Amendment to Government Regulation Number 71 of 2014 concerning Protection and Management of Peat Ecosystems, (6) Peraturan Daerah Sumatera Selatan No. 8 of 2016 concerning Forest and Land Fire Control, (7) Perpres No. 1 of 2016 concerning the Peat Restoration Agency, (8) Monograph of Gelebak Dalam Village, (9) History and Development of Gelebak Dalam Village.

In addition to documents in the form of legal regulations, various analysis and study results of the parties were obtained on community empowerment, and on the prevention and control of forest and land fires. This document is quite a lot consisting of various studies both from academics, NGOs, and the government itself. The scope is not only for Gelebak Dalam Village but also from the government.

The results obtained from the introduction of this problem, especially from the document review are as follows: (1) The causes of forest and land fires can be identified at least from several influential factors, namely: community habits in clearing land with the sonor tradition (opening land by burning), many community activities leaving the abandoned land untreated so that it can burn easily in the dry season. Another cause is the absence of plantation company activities that burn land to open new areas. (2) Karhuta issues are also related to management aspects that start from prevention programs and coordination between agencies. From various literatures it can be seen that the problem of handling forest and land fires, many are also caused by unclear management of the handling which then appears from the absence of special prevention and treatment programs. (3) Forest and land fire issues are also related to unclear or lack of clear vision about handling methods. In general, what was done was during the emergency response, so that everything, including village government officials, only focused on how to extinguish the fire. (4) Another issue of forest and land fires is the perspective of minimal creativity. There is almost no creativity that is innovative in preventing the emergence of fire. Though the potential for forest and land fire can be reduced to a minimum as long as there are strategic innovations implemented. The role of government and other elements is needed so that forest and land fire can be prevented. This innovation can be by utilizing technology or other methods. (5) Forest and Land Fire is also related to the perspective of viewing land and fire. Generally the point of view used to place fire is something that is possible and is common in the dry season. The long dry factor is the basic reason why forest and land fires always occur. Therefore the next orientation is how to put out the fire and wait for the rain to fall.

\section{Smelting with the Gelebak Dalam Community}

This stage is carried out after the researcher has an initial understanding of the problems that occur, especially the context of forest and land fire in Gelebak Dalam Village. Smelting with the community is needed because that is where the researcher mingles and then is considered part of the community. Carrying out this process certainly cannot be carried out in a short time. This is due to the fact that community merger is 
basically the integration of researchers with community groups, especially Gelebak Dalam.

To be able to fuse with the community, an understanding of the aspects of the community is needed, especially the capacity of the community. Chaskin stated that community capacity is the result of interaction of human capital, organizational resources, and social capital owned by a community that can affect collective problem solving and improve and maintain the welfare of a community. A community is also dynamic, so the capacity of a community can also change.

An understanding of these community aspects was also carried out in Gelebak Dalam Village. This understanding is obtained through the act of fusion or following the activities of the Gelebak Dalam community so that a strong understanding of the existence and existence of the community is obtained in relation to the forest and land fire issues that occur.

The method used in the researcher's melting into the Gelebak Dalam Village is as follows, (a) Conducting initial coordination with the Village Head. Formally this must be done because for the village area, the figure of the Village Head becomes an important figure who is influential. (b) Living and settling in Gelebak Dalam Village for some time. (c) Following the daily activities of the residents' agriculture. (d) After settling for some time the researcher can then participate in the activities of the residents without having to go through coordination with the Village Head.

The smelting method used by the researchers turned out to be quite effective in understanding the problem and the Gelebak Dalam community. Researchers have also conducted activities that have increasingly brought closeness to residents, such as fishing, bathing in the river, mutual cooperation, and other daily activities. All of that is in order to merge and then together with citizens begin to form an understanding of the problems that are made into a common problem.

Through this applied method, several important things that were later obtained by researchers were as follows: (1) Understanding that the Gelebak Dalam community is generally a homogeneous community in terms of ethnicity, so that it has a strong sense of family ties. Gelebak Dalam residents also have a strong sense of kinship, because they are generally of one ancestry. The sense of unity in harmony can be felt strongly, where conflicts between residents, both young people and neighbors are very rare. Including the phenomenon that is often found in other places such as land conflicts, land boundary conflicts, or theft. Almost never found. This again is influenced by the strength of the social ties that are intertwined so that the attitude of helping one another is still felt to be quite strong.

(2) Understanding that the figure of the formal village leader, in the case of the Village Head has a central role and is very important. Gelebak Dalam villagers are very obedient and follow the village chief's orders. This compliance includes other informal leaders such as Religious Leaders (Imam Masjid), traditional leaders, elders in the community. Researchers can see how the formal leaders' words and commands are followed well, even if there are differences of opinion or debate, for example in a meeting forum, the authority and power of the Village Chief still appear dominant. It is very rare for residents to show a strong attitude of rejecting the views of the Village Head.

(3) Understanding that for the community, the issue of forest and land fire is a problem that must be resolved and is very disturbing for the community. This shows that 


\section{Community Assistance for Forest and Land Fire Prevention (Karhutla) in Gelebak Dalam Village, Banyuasin District, South Sumatra \\ Yenrizal Tarmizi, Muhammad Sirozi}

there is also a shift in the meaning of forest and land fire. If there used to be an assumption that forest and land fires were caused more by weather and drought, then this understanding has now turned into a belief that this is a problem that must be resolved. This kind of understanding did not just emerge, but proceeded because of various government programs related to forest and land fires. The existence of haze, supervision from the village government, and the emergence of new solutions about forest and land fires that are innovative, causes people to begin to understand that forest and land fires can be prevented and overcome.

(4) Forest and Land Fire can be solved by innovative methods, especially the use of technological innovation. For residents of Gelebek Dalam, the habit of burning land is due to the absence of other alternatives in opening new land. The existence of new technologies, such as the launch of Bios 44, the procurement of heavy equipment, can all be important tools in emphasizing that forest and land fire can be prevented. The community basically does not want forest and land fires and hopes that there are serious and strong efforts from various parties to prevent fires from occurring.

(5) Gelebak Dalam Village actually has great potential and ability to prevent forest and land fires. This potential can be seen from how the land management and arrangement of paddy fields and settlements. Almost all of the land area in Gelebak Dalam Village has been cultivated and utilized by residents, while in 2015 there was still a lot of this land which was categorized abandoned. Land that is still in the position of shrubs, has the potential to burn. Gelebak Dalam Village actually consists of peat swamp areas, mineral swamps, and land areas. This area actually if managed properly will be able to provide positive benefits for the community. This potential is then managed and processed by the Gelebak Dalam Village Government with a variety of existing approaches.

(6) The Government of Gelebak Dalam Village apparently has its own capabilities and capacities in establishing relationships with various parties. The village head has a good relationship, especially with the military, both Korem 044 Garuda Dempo and the Banyuasin Kodim. In addition, the Village Head also has good relations with the government above him, namely the Banyuasin District and the SKPD in his neighborhood. This good relationship with various parties has become a big capital for the Village Head to later implement various programs and methods of village development. This program and method applied turned out to have a correlation with forest and land fire prevention in Gelebak Dalam Village.

(7) Understanding that in overcoming the problem of forest and land fires is needed synergy of all parties. This synergy is based on the desire and awareness that forest and land fire is a common problem and must be resisted together as well. An important strength of this synergy is the ability to see the sharing of innovation systems applied, which are then expected to provide benefits for land management and management in the Gelebak Dalam village.

The knowledge gained from this merging, methodologically obtained through various techniques carried out, either by interviews, observations, or active involvement (participant observer). It is also important here, by merging, researchers can jointly raise the awareness of citizens to jointly plan and take action to overcome and prevent forest and land fires. 
In the stages of community empowerment, planning by identifying problems is very important. This is part of participatory planning, which indeed must exist in the process of empowering a community. The involvement of the object under study in the planning process will determine the next process.

\section{Describe the identification of problems with the community}

The next stage after conducting the process of fusion with the community is to carry out the process of identifying problems with the community. In this case, the Gelebak Dalam Village community is the same or blends with researchers. Gelebak Dalam Villagers have carried out a process of raising participation and their awareness has been well developed. Researchers can come up with certain ideas about forest and land fire issues, as well as the community. This good relationship has been well established so that various programs can be implemented together.

The process in describing the identification of problems with the community is done through several processes, namely, (a) Inviting the community to jointly understand and know the problems encountered. (b) Inviting the community here is focused on the issue of forest and land fires, which then relates to various other problems. (c) Perform simulations in seeing the problem and then identify together. (d) Carry out the process of coming to the location as a place that is considered to have the potential for forest and land fires and then finding solutions together. (e) Visiting the actual location is part of the simulation carried out. At the time of the simulation, basically also conducted a review of the location of forest and land fire. While also reviewing the identification process, especially on-the-go discussions, so new ideas often emerge at this process and stage. (f) Conducting discussions with various parties related to the problem at hand, and then trying to find solutions together.

The most important of all these processes is the discussion and exchange of opinions about the problem at hand. This discussion is not just once or twice, but it is quite frequent and not required to be centered in one place. In some cases, this discussion only takes place on the edge of a rice field or the edge of a garden. While waiting for the land clearing work to finish, usually chatting with residents. Discussions like these can then provide benefits to find solutions. One solution such as excavating land and then hoarding traces of trees in the hole, the idea actually arises from discussion and chatting on the edge of rice fields.

Based on the methods of fusion to the community, to the process of identifying the problems carried out, at least the researcher can arrive at the important belief that the issue of forest and land fires in Gelebak Dalam Village has its own various problems. Some problems that can be identified are as follows:

First, the point of view in seeing that forest and land fires are a risk during the dry season. This point of view arises from the fact that forest and land fires always occur in the dry season.

In this position, when the forest and land fire occurred, many residents assumed that this was due to the forest fire effect. In other languages this is entirely considered a natural phenomenon. Words that say, "the name is dry, fire, how else," quite often heard.

This perspective is synonymous with the condition of assuming that nature is something that indeed cannot be intervened. Everything from nature is a condition that does have a correlation (Florr, 2004). 


\section{Community Assistance for Forest and Land Fire Prevention (Karhutla) in Gelebak Dalam Village, Banyuasin District, South Sumatra \\ Yenrizal Tarmizi, Muhammad Sirozi}

Second, the assumption that says that forest and land fire is something that is very disturbing for the community. The emphasis here is not on the occurrence of drought, but rather on the effect of drought, namely forest and land fire. The perceived problem with forest and land fire is haze. This is recognized by residents as something that is disturbing.

Third, the point of view that forest and land fires are a consequence of land clearing in the area. This perspective generally appeared in the past, especially before 2015. At that time it was recognized that a lot of land burning occurred as a consequence of the clearing of residents' land. However, along with various programs carried out, this perspective began to change because residents no longer burned to clear land.

Fourth, the point of view that karhutla should not happen again. Assumptions like this appear later, especially after various programs to prevent forest and land fires. The community began to believe that forest and land fire could be prevented and that it should not happen again. This belief arises because they do see that they are able to make preventive measures as well as efforts to detect early and extinguish if fire arises.

There is an interesting assumption from residents who say that it is actually not difficult to prevent forest and land fires, this is proven by what they do. If in other areas there are forest and land fires, then this is actually just a matter of not being serious in managing the residents' land.

\section{Determine alternative solutions}

From discussions with residents and frequent discussions, several alternatives have been determined to solve this problem. These alternatives are made based on an understanding of the conditions of the local problem, experience so far, and various other obstacles that were found before.

First, using technology to help farmers in opening new land that is fast and easy. This technology is not simple, at least to open the land required the existence of heavy equipment like Excavators that can replace human work. This solution was raised to assist farmers in maximizing all available land, in addition to being able to help in overcoming the problem of regulating irrigation of the irrigation path fibers in the residents' fields. Various facilities will be obtained by residents if they already have this type of tool. The problem is how to get this tool, this is where the problem occurs, because the price of an excavator is quite expensive. Discussions and discussions with residents were quite strict about this, until then the Village Head made the decision that the heavy equipment would be purchased in any way, if necessary by borrowing from a bank or other party. In this case, there is an awareness that the problem of forest and land fires can be overcome, one of them is by mechanizing agricultural land.

Second, to make certain efforts so that the agricultural land owned by residents becomes fertile, suitable for planting with satisfying results, and of course low cost. Again, this requires technology, but may not be the traditional way or use chemical products. The use of chemical products is still done by residents but this is not recommended because it then makes the land very dependent on chemical supplies. The use of chemicals that are commonly done by residents is for fertilizing and spraying pests. This did have a quick effect but it turned out to be high cost and unprofitable. Therefore, another method which is cheaper and faster is needed. 
The collaboration and networks owned by the Village Head with various agencies turned out to have a big influence. Through cooperation with Korem 044 Garuda Dempo in 2016, Bios 44 is used, a microorganism liquid whose function is able to replace the presence of chemical fertilizers. Bios 44 can be obtained easily and cheaply because it is available at Korem 044 Garuda Dempo.

Third, forest and land fire issues related to land burning activities that could have been carried out due to deliberate factors. Therefore, the method of patrolling and guarding the area from the possibility of the perpetrators of sabotage burning the land must also be anticipated. Patrol by arranging safeguards and preparedness in the dry season must be carried out.

Fourth, conduct law enforcement efforts. The trick is who burns the land, is captured and handed over to the Police. This is a method that is considered by citizens to provide a deterrent effect to other parties, that burning land, especially in Gelebak Dalam, will have a bad effect. This warning applies to all residents, both Gelebak Dalam citizens themselves or outsiders. Once again, this solution is given to provide a deterrent effect so that no one is brave enough to make an effort to burn the land.

Fifth, multiply the notice board and notice about the prohibition in burning the land. If needed it can be installed in all strategic locations that can be seen directly by residents. But the way to use announcements like this is only to give a warning, this is acknowledged by residents, that the most important thing is actually to prevent burning, not prohibit burning. Prohibition of burning will only make people afraid and then look for ways to burn, because it needs to be seen that this is just a reminder.

Sixth, seek for other livelihood opportunities from residents in the dry season, so that it does not only depend on the opening of new land. This planned effort can then make the community no longer burn land but be preoccupied with other more productive businesses. The directed effort can be in the form of fish farming, goats / cattle, salted fish processing business / sale, and various other creative businesses. This type of business is considered a side job whose results are actually quite promising. Residents also believe that a lot of potential is exploited in the village which can be a major source of raw materials. This will be very helpful, just how to make this mechanism work properly.

The problem for citizens is not the inability but rather the unconsciousness or lack of feeling the need to do the business. This will usually be answered when there are already successful practical examples from other residents. Therefore special groups need to be formed which will encourage the management and fostering of creative economic endeavors from citizens. In the dry season this will be felt very important because residents already have their own business results and then their attention will be diverted from the temptation to open new agricultural land, especially by burning the land.

Seventh, the prohibition for residents to sell their land to plantation companies or other private companies. In Gelebek Dalam, acknowledged by the Village Head, many private companies came and offered to buy large amounts of land owned by residents. The goal is to open a new oil palm plantation. The price offered is also quite high, above the market price. But the Village Head had explained to the residents not to buy land owned by the residents, because if it was done it would cause the residents to lose land and the company would then slowly "come to power" in this area.

In the process of determining alternative solutions above, the principles of participation are always put forward. For this reason, in the process, researchers together 


\section{Community Assistance for Forest and Land Fire Prevention (Karhutla) in Gelebak Dalam Village, Banyuasin District, South Sumatra \\ Yenrizal Tarmizi, Muhammad Sirozi}

with the community carried out the process of identifying and determining alternative solutions to the problem.

The method applied is a number of steps, namely, (a) Joint discussion about the issue of forest and land fires. In this research process, the quantity of informal discussion is quite large, there are at least 5 times the informal talks that can be done even more, because it is held anywhere. The parties involved in this discussion are usually community members, village officials and anyone who can attend. Researchers position themselves as people who listen and occasionally respond to what is discussed. (b) Conduct a problem mapping process. The problem mapping process usually also takes place during informal discussions. (c) The process of giving a ranking of problems. The process of determining the problem and then arriving at the solution always takes place casually and sometimes it is not realized that it is part of the process of finding a solution. (d) Location review. To ensure that the problem and the solution specified are considered appropriate and appropriate, site reviews are usually carried out. Together with residents, visited locations that are vulnerable to forest and land fires as well as see whether this solution can be taken or not.

Based on the explanation of the process that was passed above, it could be issued several recommendations that were born with the community about the prevention of forest and land fire. The recommendations agreed here are:

1. Conducting routine patrols among residents in the dry season in anticipation of forest and land fires

2. Conduct land clearing process using heavy equipment that is already owned by the village through the Village Head

3. Build water drainage ditches (simple irrigation systems) to deliver water to locations of rice fields and community plantations

4. Encourage the use of Bios 44 innovation for fertilizing agricultural land

5. Promoting the fisheries sector as an alternative livelihood for residents other than rice

6. Encourage residents to open land or maintain land that is not cultivated so that it is safe from fires in the dry season

The recommendations above are the solutions agreed upon by citizens to be carried out in anticipation of the arrival of the dry season. The recommendation was born from various conversations and assisted methods that were carried out so that it could be carried out together.

\section{Application of Solution}

After each recommendation is agreed upon, the next step is implementing the solution. The driving force in implementing this solution is the Village Head, as the formal leader in Gelebak Dalam Village. Some steps implemented by the Village Head are as follows:

1. Conducting routine patrols among residents in the dry season in anticipation of forest and land fires. The mechanism used for this solution is by:

a. Divide the community, especially adult men in certain groups. This grouping is similar to the division of post patrolling tasks, which is divided by 10 people per group whose activities take turns every day. In its implementation, this group is not prepared at all times, but they still 
monitor the situation. Other residents actually remain on standby, if it is an emergency then others immediately help. The function of this group is as an early detection and then to inform other residents.

b. Each group is asked to turn on their cellphones and report immediately if there is a fire condition.

c. Each group member is responsible for the area closest to their respective plantations, so early detection can be carried out quickly.

2. Conduct land clearing process using heavy equipment that is already owned by the village through the Village Head. The mechanism used for this activity is:

a. Prepare heavy equipment (excavator) in stand by position. This heavy equipment is equipped with special personnel who will operate it.

b. To finance the operation of heavy equipment, each resident who uses it is charged the cost of purchasing fuel in accordance with the costs incurred and the cost of the driver.

c. The Village Head and the patrol team supervise the activities of the residents, so that no more residents open land by burning.

3. Build water drainage ditches (simple irrigation systems) to deliver water to locations of rice fields and community plantations.

a. Using heavy equipment to make ditches to rice fields and residents' plantations

b. All costs incurred are charged to the village treasury using the village budget

c. Other residents help, especially residents whose land will be passed by the ditches made.

4. Encourage the use of Bios 44 innovation for fertilizing agricultural land

a. Cooperate and keep coordinating with Korem 044 Garuda Dempo as supplier of Bios 44

b. Continuing socialization with residents to use Bios 44 for agricultural technology

c. Bios 44 is used free of charge, there is no charge

5. Promoting the fisheries sector as an alternative livelihood for residents other than rice

a. Cooperating with Korem 044 Garuda Dempo to supply Bios 44 as fish feed

b. Encouraging residents whose land allows fish ponds to be made

c. Collaboration with the Banyuasin Regency Government to supply fish seeds, especially tilapia and catfish

d. In the long run create a group of fish farmers and directed to the packaging fish industry, whether in the form of salted fish or sale fish

6. Encourage residents to open land or maintain land that is not cultivated so that it is safe from fires in the dry season

a. To socialize to other residents in order to make optimal use of their land. The organizer of this socialization is the Village Head assisted by existing farmer groups.

b. Facilitating residents to clear land by providing heavy equipment and opening roads to the garden. Some locations do not yet have roads that can be passed by 4 -wheeled vehicles, therefore the village government facilitates by making roads to existing locations

c. Facilitating the creation of simple irrigation so that adequate water supply in each location.

The implementation of the above solutions starts from the entry of the 2019 dry season and continues to this day. There are benefits to be gained, because the villagers 


\section{Community Assistance for Forest and Land Fire Prevention (Karhutla) in Gelebak Dalam Village, Banyuasin District, South Sumatra \\ Yenrizal Tarmizi, Muhammad Sirozi}

have basically been guided by the Military Command 044 Garuda Dempo, so they already have an understanding of forest and land fire prevention. Researchers in this process sought to garner community participation, so ideas and ideas about forest and land fires were no longer dominated by the village head alone.

In time, the researcher will leave the location of Gelebak Dalam Village, where it is felt that the villagers are already independent and that the forest and land fire prevention system has been running well. This process will continue, even though the implementation of research is administratively considered complete.

One stage that has not yet been carried out is the process of evaluation and reflection. This can only be done when the mechanism is considered complete. Evaluation and reflection on a regular basis have actually been carried out in line with the implementation of the program in the community. It's just that a total evaluation cannot be carried out, because the process is still ongoing.

\section{Closing}

Based on the results of the assistance provided, it appears that the process of mentoring the Desa Gelebak Dalam community through certain stages is problem recognition and problem deepening, fusion with the community, determining alternative solutions to problems, and implementing alternative solutions to problems. This program has so far succeeded in building community participation and then making joint efforts to prevent and anticipate forest and land fires.

1. Some things that become community programs in preventing and overcoming forest and land fires are:

2. Conducting routine patrols among residents in the dry season in anticipation of forest and land fires

3. Conduct land clearing process using heavy equipment that is already owned by the village through the Village Head

4. Build water drainage ditches (simple irrigation systems) to deliver water to locations of rice fields and community plantations

5. Encourage the use of Bios 44 innovation for fertilizing agricultural land

6. Promoting the fisheries sector as an alternative livelihood for residents other than rice

7. Encourage residents to open land or maintain land that is not cultivated so that it is safe from fires in the dry season

Difficulties are indeed found in the mentoring process, where the role of the Village Head is very dominant, so that pure participation from community elements does not appear well. More participation is due to encouragement from the Village Head, although basically the community is aware that the problem of forest and land fires is a shared problem that must be resolved.

The research suggests that forest and land fire prevention programs in various regions in Indonesia can be carried out using community participation based assistance methods. This process is not easy, but it is a strong basis for preventing future forest and land fires. The issue of forest and land fire should not only be seen from the side of the community alone, but also in terms of policy and the role of other related elements, such as plantation companies, the government, NGOs, the Indonesian National Police. 


\section{Refference}

Budiyanto, Heri, Pendampingan Dalam Proses Perencanaan Partisipatif Program Penataan Lingkungan Permukiman Berbasis Komunitas (Plpbk), Jurnal Local Wisdom, Volume: III, Nomor: I, Halaman: 34 - 40, Februari 2011

Chaskin, J. Robert. 2001. Building Community Capacity. New York: Walter De Gruyter, Inc

Florr, Alexander G, 2004, Environmental Communications, Principe, Context, Open University Press, Philipines.

Rozaki, Abdul, 2016, Mengembangkan Model Pendampingan Desa Asimetris di Indonesia, Policy Paper, IRE, Yogyakarta

Subekti, Priyo, Yanti Setianti, dan Hanny Hafiar, Pemberdayaan Masyarakat Berbasis Lingkungan Hidup Di Desa Margalaksana Kabupaten Bandung Barat, Jurnal Kawistara, Volume 8 No 2, Agustus 2018

Widioni, Irkham dan Sarmin, Pemberdayaan Peternak Marginal: Studi Kasus di Wilayah Banguntapan Bantul, Indonesian Journal of Community Engagement Vol. 02, No. 02, Maret 2017

Yenrizal, 2008, Laporan hasil proses pemetaan awal PAR di Dusun Kemengan, Desa Wonokeling, Jatiyoso, Jawa Tengah, Tim PAR IAIN Raden Fatah dalam rangka Workshop Metodologi PAR dosen PTAI se-Indonesia, 16 Mei-5 Juni 2008

Laporan Satgas Karhutla Sumatera Selatan, tahun 2016 